(c) American Dairy Science Association, 2004.

\title{
Neutrophils in the War Against Staphylococcus aureus: Predator-Prey Models to the Rescue
}

\author{
J. C. Detilleux \\ Faculty of Veterinary Medicine and Department of Quantitative Genetics \\ University of Liège, Belgium
}

\begin{abstract}
To address the question of whether a minimum concentration of blood neutrophils is necessary to decrease Staphylococcus aureus concentration in mastitic milk, literature was searched for studies in which neutrophils were incubated with Staph. aureus. Different mathematical models that describe the changes in Staph. aureus population as a function of neutrophilic concentrations were applied to the collected data. The best fitted model established (1) that the rate of bacterial killing depended on the ratio of neutrophils to bacteria with neutrophilic attack rate accelerating at first before decelerating as the ratio increases, and (2) that neutrophil concentration should be within a limited range to trigger a decline in the bacterial population. Outcomes of this model are supported by what is known about neutrophilic functions and laboratory findings in bovine and human neutrophils. These results may be of assistance in setting selection goals for a better resilience to Staph. aureus mastitis in dairy cattle. Indeed, an optimal neutrophilic concentration appears to exist for successful clearance of Staph. aureus infection, which is neither the lowest nor the highest one.
\end{abstract}

(Key words: mastitis, neutrophil, Staphylococcus aureus, somatic cell count)

Abbreviation key: $\mathbf{F R}=$ functional response, $\mathbf{P M N}=$ polymorphonuclear neutrophil.

\section{INTRODUCTION}

Bacterial challenge of the bovine udder may lead to an inflammatory response of various degrees of severity, hereafter referred to as mastitis. Mastitis is the most prevalent and costly production disease of dairy cattle in developed countries (Fourichon et al., 1999). To reduce mastitis frequency, current methods rely heavily on therapeutic and prophylactic measures, but the cure rate for treatment with antibiotics is often

Received March 10, 2004.

Accepted July 13, 2004.

E-mail: jdetilleux@ulg.ac.be.
$<15 \%$ (Craven, 1987) for mastitis pathogen such as Staphylococcus aureus, which accounts for $>30 \%$ of clinical cases (Pyörala and Pyörala, 1997). Individual cows differ in their ability to eliminate infection from the mammary gland (Detilleux, 2002), so genetic selection of most resistant cows has been proposed as a complementary tool to classical therapeutic procedures to reduce mastitis frequency.

In dairy cattle, the most widely used character to exploit the genetic variation in mastitis resistance is the milk SCC after logarithm transformation in somatic cell scores. Somatic cells present in the milk of a healthy cow are primarily macrophages (Dosogne et al., 2001) and their count is generally below 200,000 cells $/ \mathrm{mL}$. However, once an inflammatory response has started in response to a mastitis pathogen, one observes a massive influx of blood polymorphonuclear neutrophils (PMN) into the mammary tissue and an increase in milk SCC that may reach more than $10^{6}$ cells $/ \mathrm{mL}$ with greater than 90\% of PMN (Pyörala, 2003). Those PMN have the ability to kill bacteria by phagocytosing them and exposing ingested bacteria to a variety of potent bactericidal proteins and oxidizing agents (Williams et al., 1985).

The question addressed in this paper is whether a critical PMN concentration is necessary to decrease Staph. aureus concentration in milk of infected cows. To answer this question, the methodology was to (1) search the literature for in vitro studies on bacteria growth in the presence and absence of PMN, (2) apply different models to describe the changes in bacteria concentrations, (3) identify the models that best fitted the observations, and (4) compute the PMN concentrations required from reducing Staph. aureus numbers. Although the main interest was the interrelationship between bovine PMN and Staph. aureus, information on human PMN was also considered to benefit from the knowledge accumulated there and to have a reference to which the results on bovine PMN could be compared.

\section{MATERIALS AND METHODS}

\section{The General Model}

In a suspension of bacteria and PMN, the bacterial concentration changes as a result of bacterial growth 
Table 1. In vitro growth of Staphylococcus aureus in milk-derived culture media: Observed bacterial concentrations, nonlinear estimates for the logistic $\left(b_{2}, K\right)$ and exponential $\left(b_{1}\right)$ growth parameters, and $\mathrm{R}$-square values $\left(\mathrm{R}^{2}\right)$ for the models. Standards errors of the estimates are in parentheses.

\begin{tabular}{|c|c|c|c|c|c|c|c|c|c|c|}
\hline \multirow[b]{2}{*}{ Culture medium } & \multicolumn{7}{|c|}{$\begin{array}{l}\text { Observed bacterial concentrations at different } \\
\text { times postinoculation, } \log _{10}(\mathrm{cfu} / \mathrm{mL})\end{array}$} & \multirow{2}{*}{$\begin{array}{l}\text { Logistic growth, } \\
\mathrm{b}_{2} \times 10^{-3} / \mathrm{min} \\
\mathrm{K} \times 10^{9} \mathrm{cfu} / \mathrm{mL}\end{array}$} & \multirow{2}{*}{$\begin{array}{l}\text { Exponential } \\
\text { growth } \\
\mathrm{b}_{1} \times 10^{-3} / \mathrm{min} \\
\end{array}$} & \multirow[b]{2}{*}{ References } \\
\hline & $0 \mathrm{~h}$ & $2 \mathrm{~h}$ & $4 \mathrm{~h}$ & $6 \mathrm{~h}$ & $8 \mathrm{~h}$ & $12 \mathrm{~h}$ & $24 \mathrm{~h}$ & & & \\
\hline Milk UHT & 7 & 7.5 & 8.4 & 8.5 & $\ldots$ & $\ldots$ & 9.3 & $\begin{array}{l}\mathrm{b}_{2}=13.8(2.8) \\
\mathrm{K}=0.36(0.16) \\
\mathrm{R}^{2}=93.38 \%\end{array}$ & $\begin{array}{l}\mathrm{b}_{1}=1.99(0.94) \\
\mathrm{R}^{2}=52.66 \%\end{array}$ & Ganière, 1993 \\
\hline Milk UHT & 6.5 & 7.2 & 8.5 & 8.6 & $\ldots$ & $\ldots$ & 9.0 & $\begin{array}{l}\mathrm{b}_{2}=19.2(3.7) \\
\mathrm{K}=0.42(0.13) \\
\mathrm{R}^{2}=90.66 \%\end{array}$ & $\begin{array}{l}\mathrm{b}_{1}=1.30(1.47) \\
\mathrm{R}^{2}=16.46 \%\end{array}$ & Ganière, 1999 \\
\hline Milk UHT & 7 & 7.9 & 8 & 8.2 & $\ldots$ & $\ldots$ & 9.0 & $\begin{array}{l}\mathrm{b}_{2}=13.9(3.7) \\
\mathrm{K}=0.18(0.09) \\
\mathrm{R}^{2}=90.27 \%\end{array}$ & $\begin{array}{l}\mathrm{b}_{1}=1.94(0.87) \\
\mathrm{R}^{2}=16.46 \%\end{array}$ & Ganière, 1999 \\
\hline $\begin{array}{l}\text { Skimmed cow milk } \\
\text { (14 d postcalving) }\end{array}$ & 2.48 & $\ldots$ & 3.5 & $\ldots$ & 5.31 & 6.03 & $\ldots$ & No convergence & $\begin{array}{l}\mathrm{b}_{1}=11.4(0.25) \\
\mathrm{R}^{2}=86.88 \%\end{array}$ & Dutt et al., 1986 \\
\hline $\begin{array}{l}\text { Pathogen Modeling } \\
\text { Program }\end{array}$ & 2 & 2.5 & 4.5 & 6 & 7.1 & 9 & 9 & $\begin{array}{l}\mathrm{b}_{2}=21.5(3.6) \\
\mathrm{K}=1.00(0.78) \\
\mathrm{R}^{2}=87.62 \%\end{array}$ & $\begin{array}{l}\mathrm{b}_{1}=3.88(3.64) \\
\mathrm{R}^{2}=15.90 \%\end{array}$ & $\begin{array}{l}\text { Whiting and } \\
\text { Buchanan, } 1997\end{array}$ \\
\hline
\end{tabular}

and killing of bacteria by $P M N$. Let $C_{t}$ and $M_{t}$ represent the concentrations of bacteria and PMN $(/ \mathrm{mL})$ at time $t$, respectively. The bacterial concentration at time $(t+$ $\mathrm{u})$ is:

$$
\mathrm{C}_{\mathrm{t}+\mathrm{u}}=\mathrm{C}_{\mathrm{t}} \times \mathrm{g}\left(\mathrm{C}_{\mathrm{t}}\right) \times \mathrm{h}\left(\mathrm{C}_{\mathrm{t}}, \mathrm{M}_{\mathrm{t}}\right),
$$

where $g\left(\mathrm{C}_{t}\right)$ is a function describing the rate of increase in bacterial concentration during the time period $u$, and $\mathrm{h}\left(\mathrm{C}_{\mathrm{t}}, \mathrm{M}_{\mathrm{t}}\right)$ is a function describing the rate of bacterial survival to PMN attack during the same time period.

\section{Bacterial Growth in Absence of PMN}

Under optimal laboratory conditions and classical culture media, the generation time for Staph. aureus is generally estimated at 25 to $30 \mathrm{~min}$ during the exponential growth phase. However, milk has specific properties that might lead to different growth rates, so literature was searched for published results on bacterial growth in milk (Table 1). In Ganière et al. (1993, 1999), Staph. aureus MC 660 were isolated from cases of bovine mastitis and grown in sterilized milk. In Fang et al. (1993), Staph. aureus 1.89 and 26003 were cultured in milk collected from cows with negative bacteriological results for 2 consecutive days. In Dutt et al. (1986), Staph. aureus Newbould 305 was grown in skimmed, cell-free milk collected on $\mathrm{d} 0$ and 14 postpartum. The
Pathogen Modeling Program was also used because it provides growth curves for pathogens associated with various foods under differing conditions (Whiting and Buchanan, 1997). A pH value of 6.7, an $\mathrm{NaCl}$ concentration of $0.5 \%$, and a temperature of $37^{\circ} \mathrm{C}$ were assumed for mimicking the milk environment, and the initial load was set at $10^{2} \mathrm{cfu} / \mathrm{mL}$.

\section{Bacterial Phagocytosis Assays}

Studies in which bovine (Harland et al., 1976; Roth and Kaeberle, 1981; Williams et al., 1984, 1985; Craven et al., 1986; Stevens et al., 1991; Aarestrup et al., 1994; Barrio et al., 2000; Tomita et al., 2000; Dosogne et al., 2001; Mullarky et al., 2001) or human (Pechkovscky et al., 1996; Schnyder et al., 1998; Wolach et al., 1998; Ahmed et al., 1999; Hampton and Winterbourn, 1999; Hii et al., 1999; Kaplan et al., 1999; Salih et al., 2000; Peschel et al., 2001; Chapman et al., 2002; Reeves et al., 2002) PMN were incubated with various strains of Staph. aureus at various concentrations and incubation periods were included in the study (Table 2). Classical culture media (agar gels or trypticase soy broth) and standardized procedures were used in all studies.

For each study and period of co-culture, the information needed to compute the number of bacteria killed per PMN and per unit of time was extracted. Indeed, 
Table 2. Results of a literature search on in vitro co-cultures of different strains of Staphylococcus aureus with blood neutrophils from bovine or human origins.

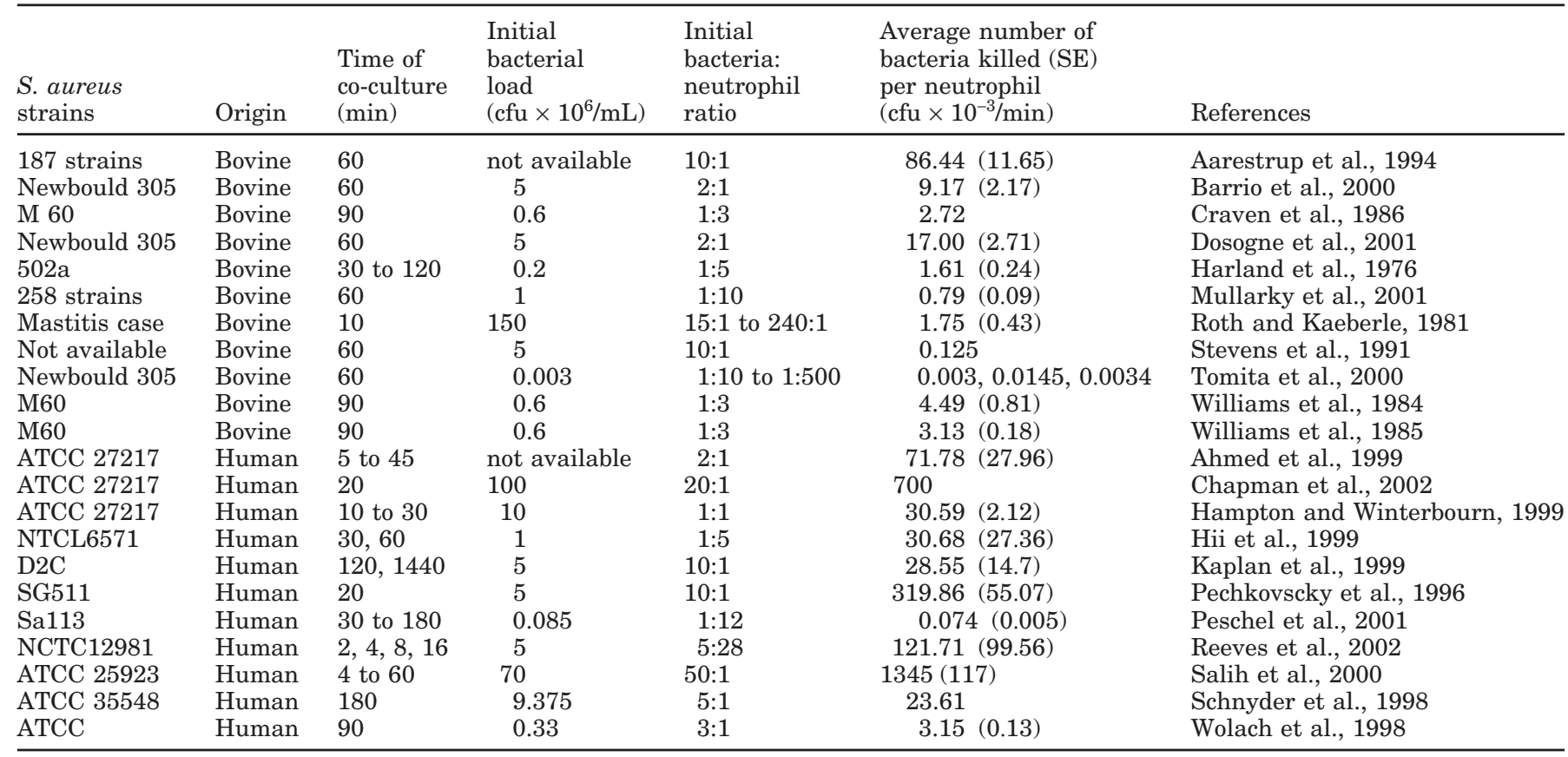

these ratio are the functional responses (see below) necessary to model $\mathrm{h}\left(\mathrm{C}_{\mathrm{t}}, \mathrm{M}_{\mathrm{t}}\right)$ in equation 1 .

\section{Models for the Bacterial Growth Rate}

When there are no PMN in bacterial culture $\left(\mathrm{M}_{\mathrm{t}}=\right.$ 0 ), equation 1 becomes $\mathrm{C}_{\mathrm{t}+\mathrm{u}}=\mathrm{C}_{\mathrm{t}} \times \mathrm{g}\left(\mathrm{C}_{\mathrm{t}}\right)$. The exponential and logistic growth functions are commonly used to model bacterial growth. In the exponential growth model, $\mathrm{C}_{\mathrm{t}+\mathrm{u}}=\mathrm{C}_{\mathrm{t}} \exp \left(\mathrm{b}_{1} \mathrm{u}\right)$ where $\mathrm{b}_{1}$ is the per capita growth rate. This model is characteristic of a population growing in a medium with unlimited resources available for growth. When bacteria compete for a limited amount of resources, there is an upper limit to population growth, called the carrying capacity, (K). Then, the per capita bacterial growth rate is $b_{2} S_{t}$, with $S_{t}=1-$ $\left(\mathrm{C}_{t} / \mathrm{K}\right)$ representing the volume available for bacteria to grow in absence of PMN, and $b_{2}$ indicating the maximum per capita growth rate when $\mathrm{S}_{\mathrm{t}}=1$ (Tsoularis and Wallace, 2002).

\section{Models for the Bacterial Survival Rate}

Let's start by describing $\mathrm{h}\left(\mathrm{C}_{\mathrm{t}}, \mathrm{M}_{\mathrm{t}}\right)$ as a Poisson process:

$$
\mathrm{h}\left(\mathrm{C}_{\mathrm{t}}, \mathrm{M}_{\mathrm{t}}\right)=\exp \left(-\mathrm{k}_{1} \mathrm{u} \mathrm{M}_{\mathrm{t}}\right)
$$

where $h\left(C_{t}, M_{t}\right)$ is the probability that bacteria escape killing by PMN during the period of time $\mathrm{u}$, and $\mathrm{k}_{1}$ is the expected proportion of $\mathrm{C}_{\mathrm{t}}$ killed per unit of time and per $\mathrm{M}_{\mathrm{t}}$. This parameter $\mathrm{k}_{1}$ may be linked to the concept of functional response (FR) extensively used in population ecology. An FR represents the number of prey (here, $\mathrm{C}_{\mathrm{t}}$ ) eaten per predator (here, $\mathrm{M}_{\mathrm{t}}$ ) and unit of time. The 10 most popular FR models, described in Jost (1998), were fitted to the data in Table 2. They express the FR as a function of either $\mathrm{C}_{t}$ (prey-dependent) or both $\mathrm{C}_{\mathrm{t}}$ and $\mathrm{M}_{\mathrm{t}}$ (predator-dependent).

In model 2, the FR model is $\mathrm{f}\left(\mathrm{C}_{\mathrm{t}}, \mathrm{M}_{\mathrm{t}}\right)=\mathrm{k}_{1} \mathrm{C}_{\mathrm{t}}$ and is called the Holling type I response. Under this model, the FR increases linearly as the prey concentration increases. Another prey-dependent FR model is the Holling type II, in which $\mathrm{f}\left(\mathrm{C}_{\mathrm{t}}, \mathrm{M}_{\mathrm{t}}\right)=\left(\mathrm{k}_{2} \mathrm{C}_{\mathrm{t}}\right) /\left[1+\mathrm{k}_{2} \mathrm{t}_{2} \mathrm{C}_{\mathrm{t}}\right]$, $\mathrm{t}_{2}$ is the time necessary for a PMN to ingest and kill a bacteria, and $\mathrm{k}_{2}$ is the constant per PMN rate of bacteria killing. In this model, it is considered that a predator spends some time to handle its prey before it can search for another, so the FR reaches a plateau when the predator becomes satiated (at high prey concentration) and the relationship between $\mathrm{f}\left(\mathrm{C}_{\mathrm{t}}, \mathrm{M}_{\mathrm{t}}\right)$ and $\mathrm{C}_{\mathrm{t}}$ is cyrtoid. In the Holling type III FR model, predators are believed to increase, at first, their search activity for a prey with increasing prey concentration before the deceleration occurring, as in the type II model, when they become satiated: $\mathrm{f}\left(\mathrm{C}_{\mathrm{t}}, \mathrm{M}_{\mathrm{t}}\right)=\mathrm{k}_{3} \mathrm{C}_{\mathrm{t}}^{2} /\left[1+\mathrm{k}_{3} \mathrm{t}_{3} \mathrm{C}_{\mathrm{t}}^{2}\right]$. This corresponds to a sigmoid relation between the $\mathrm{FR}$ and the prey concentration. Another prey-dependent FR model is referred to as the Ivlev's model, with $\mathrm{f}\left(\mathrm{C}_{\mathrm{t}}, \mathrm{M}_{\mathrm{t}}\right)=\mathrm{k}_{4}$ 
$\left(1-\exp \left(-\mathrm{a} \mathrm{C}_{\mathrm{t}}\right)\right)$, where $\mathrm{k}_{4}$ represents the maximum bacteria number a PMN can kill per unit of time and a represents the rate at which satiation is achieved. In deriving this model, it was argued that a predator's killing rate should depend on how 'hungry' a predator is, with the hunger represented as $\left[\mathrm{k}_{4}-\mathrm{f}\left(\mathrm{C}_{\mathrm{t}}, \mathrm{M}_{\mathrm{t}}\right)\right] / \mathrm{k}_{4}$.

In predator-dependent $F R$ models, $f\left(C_{t}, M_{t}\right)$ increases with $\mathrm{C}_{\mathrm{t}}$ and decreases with $\mathrm{M}_{\mathrm{t}}$. The $\mathrm{FR}$ may depend upon the bacteria to PMN ratio, as in the ratio-dependent Holling type II and type III models that correspond to the Holling type II and type III models with $\mathrm{C}_{t}$ replaced by the ratio $\mathrm{C}_{\mathrm{t}} / \mathrm{M}_{\mathrm{t}}$. There are also 2 HassellVarley models, $\mathrm{f}\left(\mathrm{C}_{\mathrm{t}}, \mathrm{M}_{\mathrm{t}}\right)=\mathrm{k}_{7}\left(\mathrm{C}_{\mathrm{t}} / \mathrm{M}_{\mathrm{t}}^{\mathrm{m}}\right)$ and $\mathrm{f}\left(\mathrm{C}_{\mathrm{t}}, \mathrm{M}_{\mathrm{t}}\right)=$ $\mathrm{k}_{8}\left(\mathrm{C}_{\mathrm{t}} / \mathrm{M}_{\mathrm{t}}^{\mathrm{m}}\right) /\left[1+\mathrm{k}_{8} \mathrm{t}_{8}\left(\mathrm{C}_{\mathrm{t}} / \mathrm{M}_{\mathrm{t}}^{\mathrm{m}}\right)\right]$ in which $\mathrm{m}$, a positive constant, estimates the degree of mutual interference among PMN in their search for bacteria. In the DeAngelis-Beddington model, a PMN allocates time to engage in encounters with other PMN, resulting in the functional response $\mathrm{f}\left(\mathrm{C}_{\mathrm{t}}, \mathrm{M}_{\mathrm{t}}\right)=\mathrm{k}_{9} \mathrm{C}_{\mathrm{t}} /\left(1+\mathrm{k}_{9} \mathrm{t}_{9} \mathrm{C}_{\mathrm{t}}+\mathrm{g}\right.$ $M_{t}$ ), where $g$ describes the magnitude of interference between PMN. This model assumes that killing and interfering are exclusive activities. Such assumptions are removed in the Crowley-Martin model that allows for interference among PMN regardless of whether a particular PMN is currently killing or searching for a bacteria: $\mathrm{f}\left(\mathrm{C}_{\mathrm{t}}, \mathrm{M}_{\mathrm{t}}\right)=\left(\mathrm{k}_{10} \mathrm{C}_{\mathrm{t}}\right) /\left(1+\mathrm{k}_{10} \mathrm{t}_{10} \mathrm{C}_{\mathrm{t}}\right)\left(1+\mathrm{d} \mathrm{M}_{\mathrm{t}}\right)$.

\section{Choice of the Best Models}

Both logistic and exponential growth models were applied to the data on bacterial growth in milk media (Table 1) and each of the 10 prey- and predator-dependent models to the FR (Table 2), keeping with the assumptions of each model (e.g., nonnegative parameters) and considering the effects of the PMN origin (human or bovine).

The models that best fitted the data were chosen 1) on the basis of the lowest sum of squares due to error, highest $\mathrm{R}$-square and adjusted R-square, and lowest root mean squared error, and 2) by verifying whether 95\% confidence intervals for the parameter include 0 .

\section{Limited Concentration of Neutrophils}

The PMN concentration needed to decrease milk bacterial concentration $\left(\mathrm{M}_{\mathrm{t}}{ }^{*}\right)$ was computed by setting $\ln \left(\mathrm{C}_{\mathrm{t}+\mathrm{u}} / \mathrm{C}_{\mathrm{t}}\right)=0$ and solving the equation. Indeed, when $\mathrm{C}_{\mathrm{t}+\mathrm{u}}=\mathrm{C}_{\mathrm{t}}, \ln \left(\mathrm{C}_{\mathrm{t}+\mathrm{u}} / \mathrm{C}_{\mathrm{t}}\right)=0$, which suggests that bacterial concentration remains stable in the interval $[\mathrm{t}, \mathrm{t}+\mathrm{u}]$. For example, with the Holling type I and the exponential growth models, equation 1 becomes:

$$
\mathrm{C}_{\mathrm{t}+\mathrm{u}}=\mathrm{C}_{\mathrm{t}} \exp \left(\mathrm{b}_{1} \mathrm{u}\right) \exp \left(-\mathrm{k}_{1} \mathrm{u} \mathrm{M}_{\mathrm{t}}\right)
$$

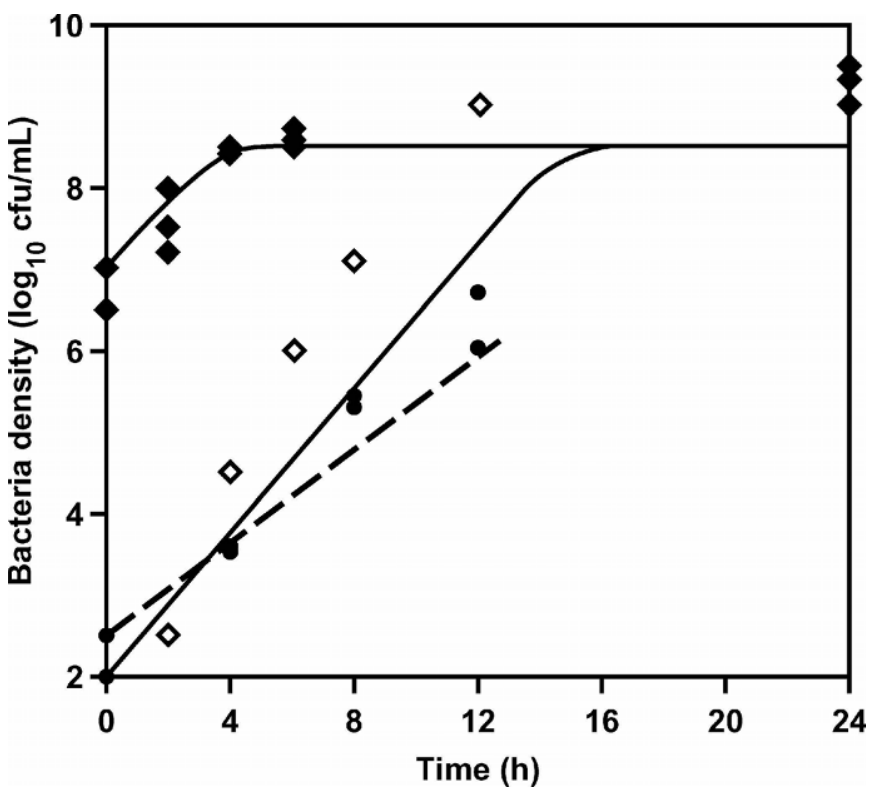

Figure 1. Bacterial growth in milk. Diamonds represent the observed bacterial concentrations used to develop the logistic growth curves (2 plain lines) for different initial bacterial concentrations. Circles represent the observed bacterial concentrations used to obtain the exponential growth curve (dashed line) before the 12th hour of culture.

Then, $\ln \left(\mathrm{C}_{\mathrm{t}+\mathrm{u}} / \mathrm{C}_{\mathrm{t}}\right)=0$ when $\mathrm{M}_{\mathrm{t}}{ }^{*}=\mathrm{b}_{1} / \mathrm{k}_{1}$. Similarly, using Holling type III for $\mathrm{f}\left(\mathrm{C}_{\mathrm{t}}, \mathrm{M}_{\mathrm{t}}\right)$ and the logistic growth model for $\mathrm{g}\left(\mathrm{C}_{\mathrm{t}}\right)$, equation 1 becomes:

$\mathrm{C}_{\mathrm{t}+\mathrm{u}}=\mathrm{C}_{\mathrm{t}} \exp \left(\mathrm{b}_{2} \mathrm{~S}_{\mathrm{t}} \mathrm{u}\right) \exp \left(-\mathrm{k}_{3} \mathrm{C}_{\mathrm{t}} \mathrm{u} \mathrm{M}_{\mathrm{t}} /\left[1+\mathrm{k}_{3} \mathrm{t}_{3} \mathrm{C}_{\mathrm{t}}^{2}\right]\right)$

and $\ln \left(\mathrm{C}_{\mathrm{t}+\mathrm{u}} / \mathrm{C}_{\mathrm{t}}\right)=0$ when $\mathrm{M}_{\mathrm{t}} *=\left[\left(\mathrm{b}_{2} / \mathrm{k}_{3}\right) *\left(\mathrm{~S}_{\mathrm{t}} / \mathrm{C}_{\mathrm{t}}\right)\right]+\left[\mathrm{b}_{2}\right.$ $\left.\mathrm{t}_{3} \mathrm{~S}_{\mathrm{t}} \mathrm{C}_{\mathrm{t}}\right]$.

\section{RESULTS}

\section{Bacterial Growth Rates}

Only the exponential model could be applied to changes in bacterial concentrations before $12 \mathrm{~h}$ postinoculation. Alternatively, the logistic model had the lowest $R^{2}$ when the bacterial population was allowed to grow for more than $12 \mathrm{~h}$ (Table 1). Growth parameters' weighted (weight $=$ inverse of the variance of individual estimates) averages were $11.12 \times 10^{-3} / \mathrm{min}$ for $b_{1}$ and $17.21 \times 10^{-3} / \mathrm{min}$ for $b_{2}$, for a duration of bacterial growth up to $12 \mathrm{~h}$ and more than $12 \mathrm{~h}$, respectively. The carrying capacity was estimated at $335 \times 10^{6} \mathrm{cfu} / \mathrm{mL}$. Observed bacterial concentrations and concentrations obtained with the weighted averages are shown in Figure 1 . 
Table 3. Nonlinear estimates ${ }^{1}$ of the parameters for the functional responses as a function of the bacterial and neutrophilic concentrations, according to the neutrophils' origin.

\begin{tabular}{|c|c|c|c|c|}
\hline Functional response & $\mathrm{R}^{2}(\%)$ & $\begin{array}{l}\text { Bovine blood } \\
\text { neutrophil } \\
\text { estimates (SE) }\end{array}$ & $\mathrm{R}^{2}(\%)$ & $\begin{array}{l}\text { Human blood } \\
\text { neutrophil } \\
\text { estimates (SE) }\end{array}$ \\
\hline Holling type I & 85.14 & $\mathrm{k}_{1}=0.68(0.05) \times 10^{-8}$ & 47.88 & $\mathrm{k}_{1}=0.85(0.67) \times 10^{-8}$ \\
\hline Holling type II & 98.33 & $\begin{array}{l}\mathrm{k}_{2}=2.28(0.29) \times 10^{-8} \\
\mathrm{t}_{2}=0.23(0.01)\end{array}$ & 56.35 & $\begin{array}{l}\mathrm{k}_{2}=1.40(4.70) \times 10^{-5} \\
\mathrm{t}_{2}=2.24(0.57)\end{array}$ \\
\hline Holling type III & 99.38 & $\begin{array}{l}\mathrm{k}_{3}=2.39(0.16) \times 10^{-16} \\
\mathrm{t}_{3}=0.31(0.006)\end{array}$ & 59.97 & $\begin{array}{l}\mathrm{k}_{3}=3.24(9.24) \times 10^{-11} \\
\mathrm{t}_{3}=2.14(0.47)\end{array}$ \\
\hline Ivlev & 98.73 & $\begin{array}{l}\mathrm{k}_{4}=3.28(0.12) \\
\mathrm{a}=5.97(0.52) \times 10^{-9}\end{array}$ & 60.47 & $\begin{array}{l}\mathrm{k}_{4}=0.47(0.10) \\
\mathrm{a}=6.59(9.30) \times 10^{-6}\end{array}$ \\
\hline $\begin{array}{l}\text { Ratio-dependent } \\
\text { Holling type II }\end{array}$ & 96.43 & $\begin{array}{l}\mathrm{k}_{5}=4.56(0.49) \times 10^{-2} \\
\mathrm{t}_{5}=0.20(0.02)\end{array}$ & 93.92 & $\begin{array}{l}\mathrm{k}_{5}=2.97(0.65) \times 10^{-2} \\
\mathrm{t}_{5}=0.07(0.15)\end{array}$ \\
\hline $\begin{array}{l}\text { Ratio-dependent } \\
\text { Holling type III }\end{array}$ & 99.43 & $\begin{array}{l}\mathrm{k}_{6}=1.49(0.01) \times 10^{-3} \\
\mathrm{t}_{6}=0.31(0.01)\end{array}$ & 94.10 & $\begin{array}{l}\mathrm{k}_{6}=3.26(0.79) \times 10^{-3} \\
\mathrm{t}_{6}=0.62(0.04)\end{array}$ \\
\hline Hassell-Varley type I & 85.17 & $\begin{array}{l}\mathrm{k}_{7}=1.07(2.80) \times 10^{-3} \\
\mathrm{~m}=0.81(1.78)\end{array}$ & 94.01 & $\begin{array}{l}\mathrm{k}_{7}=2.09(0.77) \times 10^{-2} \\
\mathrm{~m}=0.97(0.04)\end{array}$ \\
\hline Hassell-Varley type II & 98.34 & $\begin{array}{l}\mathrm{k}_{8}=4.09(29.12) \times 10^{-7} \\
\mathrm{t}_{8}=0.23(0.01) \\
\mathrm{m}=0.19(0.48)\end{array}$ & 94.07 & $\begin{array}{l}\mathrm{k}_{8}=0.01(0.011) \\
\mathrm{t}_{8}=-0.27(0.49) \\
\mathrm{m}=0.93(0.06)\end{array}$ \\
\hline DeAngelis-Beddington & 98.35 & $\begin{array}{l}\mathrm{k}_{9}=3.27(3.43) \times 10^{-8} \\
\mathrm{t}_{9}=0.23(0.01) \\
\mathrm{m}=1.74(6.03) \times 10^{-7}\end{array}$ & & No convergence \\
\hline Crowley-Martin & & No convergence & & No convergence \\
\hline
\end{tabular}

\footnotetext{
${ }^{1} k_{i}=$ expected proportion of bacteria killed per neutrophil per min; $t_{i}=$ time in min spent by the neutrophil
} to handle bacteria; and $\mathrm{i}=1,2, \ldots, 10$ functional response models.

\section{Functional Responses}

Based on the $\mathrm{R}^{2}$ values, both the ratio-dependent and the Holling type III models fitted most closely the observed bacterial killing rates (Table 3). However, when considering bovine PMN, the ratio-dependent Holling type III model had the lowest sum of squared residuals $\left(15.3 \times 10^{-2}\right.$ vs. $\left.16.7 \times 10^{-2}\right)$, the lowest root mean squared error $\left(7.02 \times 10^{-2}\right.$ vs. $\left.7.33 \times 10^{-2}\right)$, and it fitted best the observed FR at a small bacteria:PMN ratio (Figure 2). For human PMN, only parameters from the ratio-dependent Holling type III model were statistically different from 0 , with $95 \%$ confidence intervals equal to $\left(1.66 \times 10^{-3} ; 4.86 \times 10^{-3}\right)$ for $\mathrm{k}_{6}$ and $(0.53 ; 0.71)$ for $t_{6}$.

\section{Limited Concentrations of Neutrophils}

Under the ratio-dependent Holling type III model, lower and upper PMN limits below and above which the bacterial concentration increases were obtained as:

$$
\mathrm{M}_{\mathrm{t}}^{*}=\mathrm{C}_{\mathrm{t}} *\left\{\mathrm{k}_{6} \pm\left[\left(\mathrm{k}_{6}^{2}-4 \mathrm{~b}^{2} \mathrm{k}_{6} \mathrm{t}_{6}\right)\right]^{1 / 2}\right\} /(2 \mathrm{~b}),
$$

with $b=$ bacterial growth rate under the logistic or exponential models. Then, the ranges for $\mathrm{M}_{\mathrm{t}} * / \mathrm{C}_{\mathrm{t}}$ are $\left[5.71 \times 10^{-3} ; 80.8 \times 10^{-3}\right]$ for bovine and $\left[11.35 \times 10^{-3}\right.$; $178.07 \times 10^{-3}$ ] for human PMN with $\mathrm{b}=17.21 \times 10^{-3}$.
With the basic model $3, \mathrm{M}_{\mathrm{t}}^{*}=1.64 \times 10^{6}$ and 1.31 $\times 10^{6} \mathrm{PMN} / \mathrm{mL}$ for PMN originating from bovine and human blood, respectively.

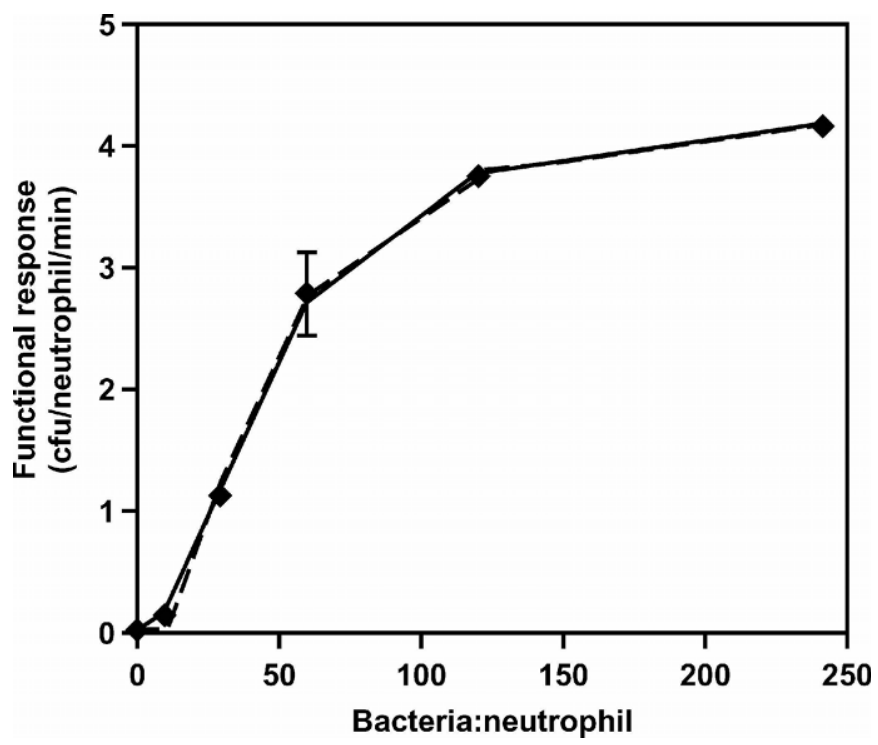

Figure 2. Functional response of bovine blood neutrophils. Values observed (diamonds) and estimated with the Holling (dashed line) and ratio-dependent (plain line) type III functional response models. 


\section{DISCUSSION}

Different predator-prey models were used to explore the changes in bacterial concentrations in the presence of their predator, the PMN. Of course, these models are a simplified version of the reality. Thus, it was assumed that every Staph. aureus was equally vulnerable to PMN killing even though significant variation was shown between PMN bactericidal capacity against different strains of Staph. aureus (Aarestrup et al., 1994; Mullarky et al., 2001; Peschel et al., 2001). Constant PMN per capita rates of killing were also assumed, although aged and juvenile PMN do not have the same killing ability (Sladek et al., 2002). With such assumptions, some information was lost, but the models had the advantages to concentrate on the most important parameters in describing PMN-bacteria interactions. Because of their mathematical properties, the models also predict the behavior of the system over the long run and provide clues for a better understanding of the particularities of the PMN-bacteria interactions.

Problems also exist when combining data from different studies (e.g., differences in investigators, culture media, bacterial strains) especially because studies on bovine PMN killing functions are relatively rare when compared with human studies. In an attempt to decrease the impact of such problems in the interpretation of the results, data on human PMN functions were collected and compared with results obtained on bovine PMN.

\section{Bacterial Growth Rates}

Bacterial growth in bovine milk was slower than in classical trypticase soy broth medium. This was expected because normal milk contains proteins such as lactoferrin, lysozyme, and lactoperoxidase that have antibacterial properties (Reiter, 1978).

\section{Functional Responses}

The ratio-dependent type III was the best model for describing the FR based on goodness-of-fit statistics and significance of the parameters estimates. According to Jost and Ellner (2000), goodness-of-fit is indeed an appropriate method to select between prey- and ratiodependent FR. Although the ratio dependency is not supported by the results of $\mathrm{Li}$ et al. (2002) on human PMN, it is corroborated by laboratory analyses on the variation in Staph. aureus concentrations in the presence of human (Gresham et al., 2000) and bovine (Tomita et al., 2000; Dosogne et al., 2001) PMN. It is also substantiated by the argument that FR are mechanistically ratio-dependent when the region where predators can encounter prey is of limited size (Cosner et al.,

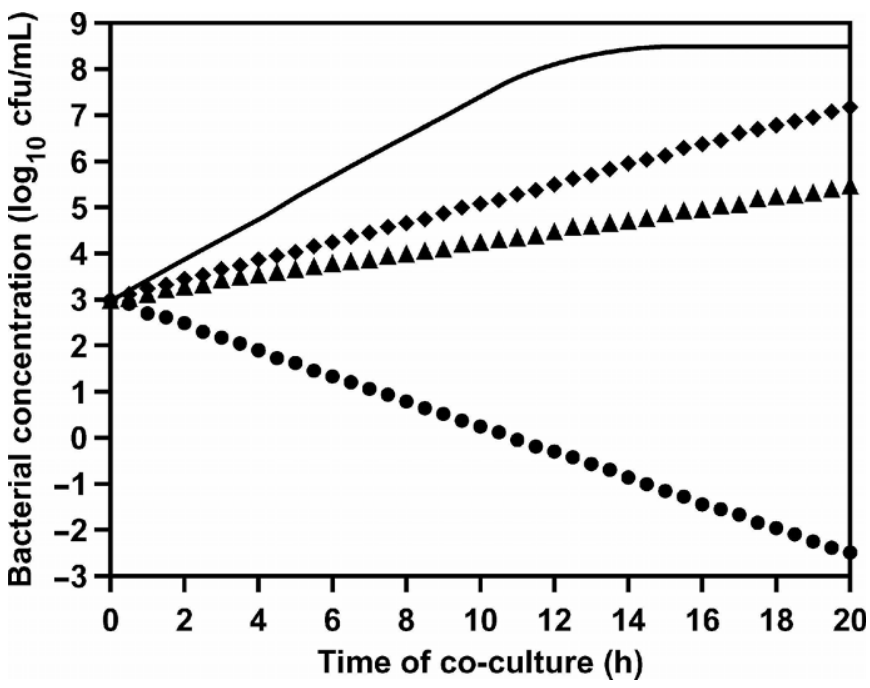

Figure 3. Bacterial concentrations across time for bovine neutrophilic concentrations above (diamonds), below (triangles), and within (circles) the limits estimated with the ratio-dependent type III model. The plain line represents bacterial growth in the absence of polymorphonuclear neutrophils.

1999). An FR of type III (sigmoid) is also sensible because, at constant concentration, PMN can only regulate bacterial population if the bacterial killing rate increases with increasing bacterial concentration. In the type I (linear) response, this bacterial mortality rate is constant and in the type II (cyrtoid) response, it declines.

Estimates for the parameters of the FR models (Table 3) were compared with published estimates of Staph. aureus killing rates. Such estimates could only be found in studies with human blood PMN and only for the parameter of the Holling type I response. In the study of Hampton and Winterbourn (1999), $\mathrm{k}_{1}=0.83 \times 10^{-8}$ which is very close to our result $\left(\mathrm{k}_{1}=0.85 \times 10^{-8}\right)$. Chapman et al. (2001) observed a half-life of $9 \mathrm{~min}$ when $10^{8}$ Staph. aureus were added to $5 \times 10^{6} \mathrm{PMN}$, which gives $\mathrm{k}_{1}=1.32 \times 10^{-8}$. Li et al. (2002) observed Staph. aureus killing rates varying from 0.9 to $2.1 \times$ $10^{-8} / \mathrm{PMN}$ per min.

Killing rate was lower for bovine $\left(\mathrm{k}_{6}=1.49 \times 10^{-3}\right)$ than human $\left(\mathrm{k}_{6}=3.26 \times 10^{-3}\right) \mathrm{PMN}$. Indeed, bovine PMN lack N-formyl-peptide chemotactic receptors and have little or no lysozyme in their granules (Styrt, 1989).

\section{Limited Concentrations of Neutrophils}

Another finding of the ratio-dependent type III model was that in vitro bacterial growth is controlled when PMN concentration is within limits. When the PMN concentration is outside the limits, bacterial concentration increases, as shown in Figure 3 for initial load $\mathrm{C}_{0}=$ 
$10^{3} \mathrm{cfu} / \mathrm{mL}$. In vivo, Paape et al. (1981) showed that infection failed to occur after challenge with 23.8 to $115.0 \mathrm{cfu}$ of Staph. aureus strain 305 when the concentration of somatic cells was $8.8 \times 10^{5}$ or greater per $\mathrm{mL}$ at the time of challenge. Postle et al. (1978) could induce infection with $100 \mathrm{cfu}$ of Staph. aureus when the concentration of somatic cells was $6 \times 10^{5}$ or less per $\mathrm{mL}$ at the time of challenge. Schultze and Paape (1984) revealed a concentration of milk PMN of $9 \times 10^{5} / \mathrm{mL}$ is required to prevent infection with Staph. aureus. When PMN concentrations are above the highest limit, PMN may act as a reservoir for Staph. aureus. Indeed, Staph. aureus has the ability to gain access to a locale within PMN where it is prevented from being killed (Hebert et al., 2000). Those intracellular Staph. aureus are then released when PMN are disrupted during apoptosis. In experimental in vivo studies, Gresham et al. (2000) showed that restricting PMN migration into the peritoneum of mice challenged intraperitoneally with Staph. aureus resulted in a significant decrease in bacterial burden.

The bacteria to PMN ratio desirable for effective phagocytosis and killing of Staph. aureus was 10:1 (Daniel et al., 1991), 16:1 (Paape et al., 1978), 20:1 (Guidry et al., 1991), and 40:1 (O'Brien et al., 2000) in some studies other than those used in Table 2. All are within the limits of $12: 1$ and $175: 1$ obtained with the ratio-dependent type III model. Such limits may explain the cyclic increase and decrease in the quantity of SCC and viable Staph. aureus shed in the milk $3 \mathrm{wk}$ after experimental infusion into the teat cistern of 50 to 80 cfu, as observed by Burton and Kehrli (1995), Daley et al. (1991), and Paape et al. (1981). Let's assume the concentration of PMN resident in the gland at the time of infection is not sufficient to jugulate the bacterial growth. Then, Staph. aureus proliferate, which causes an influx of active blood PMN in the gland. As soon as the number of migrating blood PMN is within the range delimited by the ratio-dependent type III model, the bacterial concentration will start to decrease. The stimulus for the influx of PMN will drop off and their number may decrease below the lowest limit. The residual or viable intracellular bacteria are then permitted to grow and the cycle starts again. This explanation was first proposed by Daley et al. (1991). The ratio-dependent type III model also proposes an upper limit to the PMN concentration. Indeed, the inflammatory response to bacterial challenge may be so intense that the number of blood PMN reaches above the highest limit. Then, the model hypothesizes an acceleration of bacterial multiplication until they reach the carrying capacity. This may explain the absent relationship between SCC and Staph. aureus colony-forming units as observed by Schultze and Paape (1984).
From a selection point of view, it was interesting to appreciate that cows with too few or too many PMN at the site of infection could be less able to control the growth of a Staph. aureus population. It is theoretically possible to select for cows with PMN within the limited range because significant genetic variation has been shown in the bovine for blood PMN counts (Tempelman et al., 2002), for their ability to kill bacteria through oxygen-dependent mechanisms, and their ability to migrate in vitro (Detilleux et al., 1994). From the ratiodependent type III model, selection could be for an increase in PMN killing rate $\left(\mathrm{k}_{6}\right)$ or a decrease in the time necessary for a PMN to handle bacteria $\left(\mathrm{t}_{6}\right)$. A decrease in $t_{6}$ is associated with a decrease in the lower limit and an increase in the upper limit of the limited range. An increase in $\mathrm{k}_{6}$ results in a higher upper limit with no significant changes in the lower limit of the limited range. However, because there are legal limits on number of PMN in marketable milk, the best decision would be to decrease $t_{6}$.

Of course, caution against an overgeneralization of the results of this study to in vivo Staph. aureus infections is necessary. Further research is needed to better characterize the effects of the different elements of an in vivo interaction between PMN and bacteria (e.g., PMN release from the bone marrow, hormonal status, endothelial migration). However, the results obtained in this study for bovine PMN were similar to those of Li et al. (2002) for human PMN. Namely, the PMN concentration at which the rate of bacterial growth matches the rate of bacterial killing $\left(\mathrm{M}_{\mathrm{t}}{ }^{*}=1.64 \times 10^{6}\right)$ is below the normal range of blood PMN (1.8 to $7.7 \times$ $10^{6}$ blood PMN $/ \mathrm{mL}$ ).

\section{CONCLUSIONS}

After a literature search, different prey-predator models were developed to fit changes in Staph. aureus milk concentrations in the presence of bovine or human neutrophils. The model that best fitted the observed data is a model with only 3 parameters (bacteria growth rate, PMN handling time, and PMN killing rate). It is characterized by 1) a neutrophilic attack rate accelerating at first before decelerating as the bacteria-to-neutrophil ratio increases, and 2) the requirement of having neutrophilic concentrations within a limited range to trigger a decline in the bacterial population. The model predicts not only that the regulating effect of PMN on bacteria density is lost when bacteria are above the upper limit but also bacteria density will increase rapidly until it reaches eventually the carrying capacity.

Although caution against overgeneralization is necessary, results of this study are supported by different in vitro and in vivo findings and should help in resolving 
the controversial issue of whether an optimum count of PMN is necessary to clear a Staph. aureus mammary infection.

\section{REFERENCES}

Aarestrup, F. M., N. L. Scott, and L. M. Sordillo. 1994. Ability of Staphylococcus aureus coagulase genotypes to resist neutrophil bactericidal activity and phagocytosis. Infect. Immun. 62:56795682 .

Ahmed, N. A., S. McGill, J. Yee, F. Hu, R. P. Michel, and N. V. Christou. 1999. Mechanisms for the diminished neutrophil exudation to secondary inflammatory sites in infected patients with a systemic inflammatory response. Crit. Care Med. 27:2459-2468.

Barrio, B., F. Vangroenweghe, H. Dosogne, and C. Burvenich. 2000. Decreased neutrophil bactericidal activity during phagocytosis of a slime-producing Staphylococcus aureus strain. Vet. Res. 31:603-609.

Burton, J. L., and M. Kehrli, Jr. 1995. Regulation of neutrophil adhesion molecules and shedding of in milk of cortisol- and dexamethasone-treated cows. Am. J. Vet. Res. 56:997-1003.

Chapman, A. L. P., M. B. Hampton, R. Senthilmohan, C. C. Winterbourn, and A. J. Kettle. 2002. Chlorination of bacterial and neutrophil proteins during phagocytosis and killing of Staphylococcus aureus. J. Biol. Chem. 277:9757-9762.

Cosner, C., D. DeAngelis, J. S. Ault, and D. B. Olson. 1999. Effects of spatial grouping on the functional response of predators. Theor. Popul. Biol. 56:65-75.

Craven, N. 1987. Efficacy and financial value of antibiotic treatment of bovine clinical mastitis during lactation-A review. Br. Vet. J. 143:410-422.

Craven, N., M. R. Williams, T. R. Field, K. J. Bunch, S. J. Mayer, and F. J. Bourne. 1986. The influence of extra-cellular and phagolysosomal $\mathrm{pH}$ changes on the bactericidal activity of bovine neutrophils against Staphylococcus aureus. Vet. Immunol. Immunopathol. 13:97-110.

Daley, M. J., E. R. Oldham, T. J. Williams, and P. A. Coyle. 1991. Quantitative and qualitative properties of host polymorphonuclear cells during experimentally induced Staphylococcus aureus mastitis in cows. Am. J. Vet. Res. 52:474-479.

Daniel, R., B. P. Chew, T. S. Tanaka, and L. W. Tjoelker. 1991. Betacarotene and vitamin A effects on bovine phagocyte function in vitro during the peripartum period. J. Dairy Sci. 74:124-131.

Detilleux, J. 2002. Genetic factors affecting susceptibility of dairy cows to udder pathogens. Vet. Immunol. Immunopathol. 88:103-110.

Detilleux, J., K. J. Koehler, A. E. Freeman, M. E. Kehrli, and D. H. Kelley. 1994. Immunological parameters of periparturient Holstein cattle: Genetic variation. J. Dairy Sci. 77:2640-2650.

Dosogne, H., F. Vangroenweghe, B. Barrio, P. Rainard, and C. Burvenich. 2001. Decreased number and bactericidal activity against Staphylococcus aureus of the resident cells in milk of dairy cows during early lactation. J. Dairy Res. 68:539-549.

Dutt, K. W., R. J. Eberhart, and R. A. Wilson. 1986. In vitro growth of mastitis pathogens in mammary secretions of the dry and peripartum periods. J. Dairy Sci. 69:2408-2415.

Fang, W., M. Shi, L. Huang, Q. Shao, and J. Chen. 1993. Growth of lactobacilli, Staphylococcus aureus and Escherichia coli in normal and mastitic milk and whey. Vet. Microbiol. 37:115-125.

Fourichon, C., H. Seegers, N. Bareille, and F. Beaudeau. 1999. Effects of disease on milk production in the dairy cow: A review. Prev. Vet. Med. 41:1-35.

Ganière, J. P., G. Andre-Fontaine, and M. Larrat. 1993. Cinétique de bactéricide in vitro d'une association antibiotique en solution dans du lait. Rec. Méd. Vét. 21:155-163.

Ganière, J. P., N. Ruvoen, G. Andre-Fontaine, and M. Larrat. 1999. Application de la cinétique de bactéricide à l'étude de l'activité in vitro des antibiotiques dans le lait. Journées Nationales GTVINRA 1:33-40.
Gresham, H. D., T. E. Lowrance, B. S. Wilson, A. L. Cheung, and F. P. Lindberg. 2000. Survival of Staphylococcus aureus inside neutrophils contributes to infection. J. Immunol. 164:3713-3722.

Guidry, A. J., S. P. Oliver, K. E. Squiggins, E. F. Erbe, H. H. Dowlen, C. N. Hambleton, and L. M. Berning. 1991. Effect of anticapsular antibodies on neutrophil phagocytosis of Staphylococcus aureus. J. Dairy Sci. 74:3360-3369.

Hampton, M. B., and C. C. Winterbourn. 1999. Methods for quantifying phagocytosis and bacterial killing by human neutrophils. J. Immunol. Methods 232:15-22.

Harland, W. R., P. E. William, L. T. David, and W. F. Floyd. 1976 Antibacterial host defense: In vitro interaction of bacteria, serum factors, and leukocytes from precolostral dairy calves and their dams. Am. J. Vet. Res. 37:1267-1274.

Hebert, A., K. Sayasith, S. Senechal, P. Dubreuil, and J. Lagace. 2000. Demonstration of intracellular Staphylococcus aureus in bovine mastitis alveolar cells and macrophages isolated from naturally infected cow milk. FEMS Microbiol. Lett. 193:57-62.

Hii, C. S. T., K. Stacey, N. Moghaddami, A. W. Murray, and A. Ferrantel. 1999. Role of the extracellular signal-regulated protein kinase cascade in human neutrophil of Staphylococcus aureus and Candida albicans and in migration. Infect. Immun. 67:1297-1302.

Jost, C. 1998. Comparing predator-prey models qualitatively and quantitatively with ecological time-series data. Ph.D. Diss., Institut National Agronomique, Paris-Grignon, France.

Jost, C., and S. P. Ellner. 2000. Testing for predator dependence in predator-prey dynamics: A non-parametric approach. Proc. $\mathrm{R}$. Soc. Lond. 267:1611-1620.

Kaplan, S. S., R. P. Heine, and R. L. Simmons. 1999. Defensins impair phagocytic killing by neutrophils in biomaterial-related infection. Infect. Immun. 67:1640-1645.

Li, Y., A. Karlin, J. D. Loike, and S. C. Silverstein. 2002. A critical concentration of neutrophils is required for effective bacterial killing in suspension. Proc. Natl. Acad. Sci. USA 99:8289-8294.

Mullarky, I. K., C. Su, N. Frieze, Y. H. Park, and L. M. Sordillo. 2001. Staphylococcus aureus agr genotypes with enterotoxin production capabilities can resist neutrophil bactericidal activity. Infect. Immun. 69:45-51.

O'Brien, C. N., A. J. Guidry, A. Fattom, S. Shepherd, L. W. Douglass, and D. C. Westhoff. 2000. Production of antibodies to Staphylococcus aureus serotypes 5, 8, and 336 using poly(DL-lactide-co-glycolide) microspheres. J. Dairy Sci. 83:1758-1766.

Paape, M. J., R. E. Pearson, and W. D. Schultze. 1978. Variation among cows in the ability of milk to support phagocytosis and in the ability of polymorphonuclear leukocytes to phagocytose Staphylococcus aureus. Am. J. Vet. Res. 39:1907-1910.

Paape, M. J., W. D. Schultze, A. J. Guidry, W. M. Kortum, and B. T. Weinland. 1981. Effect of an intra-mammary polyethylene device on the concentration of leukocytes and immunoglobulins in milk and on the leukocyte response to Escherichia coli endotoxin and challenge exposure with Staphylococcus aureus. Am. J. Vet. Res. 42:774-783.

Pechkovsky, D. V., M. P. Potapnev, and O. M. Zalukskaya. 1996. Different patterns of cytokine regulation of phagocytosis and bacterial killing by human neutrophils. Int. J. Antimicrob. Agents 7:33-40.

Peschel, A., R. W. Jack, M. Otto, L. V. Collins, P. Staubitz, G. Nicholson, H. Kalbacher, W. F. Nieuwenhuizen, G. Jung, A. Tarkowski, K. P. M. van Kessel, and J. A. G. van Strijp. 2001. Staphylococcus aureus resistance to human defensins and evasion of neutrophil killing via the novel virulence factor $\mathrm{MprF}$ is based on modification of membrane lipids with L-lysine. J. Exp. Med. 193:10671076.

Postle, D. S., M. Roguinsky, and B. Poutrel. 1978. Induced staphylococcal infections in the bovine mammary gland. Am. J. Vet. Res. 39:29-35.

Pyörala, S. 2003. Indicators of inflammation in the diagnosis of mastitis. Vet. Res. 34:565-578.

Pyörala, S., and E. Pyörala. 1997. Accuracy of methods using somatic cell count and N-acetyl-beta- D-glucosaminidase activity in milk 
to assess the bacteriological cure of bovine clinical mastitis. J. Dairy Sci. 80:2820-2825.

Reeves, E. P., H. Lu, H. L. Jacobs, C. G. M. Messina, S. Bolsover, G. Gabella, E. O. Potma, A. Warley, J. Roes, and A. W. Segal. 2002. Killing activity of neutrophils is mediated through activation of protease by $\mathrm{K}^{+}$flux. Nature 416:291-295.

Reiter, B. 1978. Antimicrobial systems in milk. J. Dairy Res. 45:131-147.

Roth, J. A., and M. L. Kaeberle. 1981. Evaluation of bovine polymorphonuclear leukocyte function. Vet. Immunol. Immunopathol. 2:157-174.

Salih, H. R., L. Husfeld, and D. Adam. 2000. Simultaneous cytofluorometric measurement of phagocytosis, burst production and killing of human phagocytes using Candida albicans and Staphylococcus aureus as target organisms. Clin. Microbiol. Infect. 6:251-258.

Schnyder, B., P. C. Meunier, and B. D. Car. 1998. Inhibition of kinases impairs neutrophil activation and killing of Staphylococcus aureus. Biochem. J. 331:489-495.

Schultze, W. D., and M. J. Paape. 1984. Effect of outcome of intramammary challenge exposure with Staphylococcus aureus of somatic cell concentration and presence of an intramammary device. Am. J. Vet. Res. 44:427-429.

Sladek, Z., D. Vasickova, and D. Rysaneck. 2002. The dynamics of morphological changes during in vitro aging of bovine virgin mammary gland neutrophils. Vet. Med. Czech. 47:325-332.
Stevens, M. G., M. E. Kehrli, Jr., and P. C. Canning. 1991. A colorimetric assay for quantitating bovine neutrophil bactericidal activity. Vet. Immunol. Immunopathol. 28:45-56.

Styrt, B. 1989. Species variation in neutrophil biochemistry and function. J. Leukoc. Biol. 46:63-74.

Tempelman, R. J., P. M. Saama, A. E. Freeman, S. C. Kelm, A. L. Kuck, M. E. Kehrli, Jr., and J. L. Burton. 2002. Genetic variation in bovine neutrophil sensitivity to glucocorticoid challenge. Acta Agric. Scand. A. Anim. Sci. 52:189-202.

Tomita, G. M., Y. Wang, M. J. Paape, B. Poutrel, and P. Rainard. 2000. Influence of biospecific antibodies on the in vitro bactericidal activity of bovine neutrophil against Staphylococcus aureus. J. Dairy Sci. 83:2269-2275.

Tsoularis, A., and J. Wallace. 2002. Analysis of logistic growth models. Math. Biosci. 179:21-55.

Whiting, R. C., and R. L. Buchanan. 1997. Development of a quantitative risk assessment model for Salmonella enteritidis in pasteurized eggs. Int. J. Food Microbiol. 36:111-126.

Williams, M. R., N. Craven, T. R. Field, and K. J. Bunch. 1985 The relationship between phagocytosis and intracellular killing of Staphylococcus aureus by bovine neutrophils. Br. Vet. J. 141:362-371.

Williams, M. R., K. G. Hibbit, T. R. Field, and K. J. Bunch. 1984. Further studies on the variation among cows, bulls and calves in the ability of their blood polymorphonuclear leucocytes to kill Staphylococcus aureus. Br. Vet. J. 140:307-313.

Wolach, B., R. Gavrieli, Y. Manor, and M. Lishner. 1998. Leukocyte function in chronic myeloproliferative disorders. Blood Cells Mol. Dis. 24:544-551. 